\title{
SLAUGHTER QUALITY OF BROILER-CHICKENS BY PREBIOTIC ACTIGEN USING
}

\section{Chernikova Ganna*, Prokopenko Nataliia}

National University of Life and Environmental Sciences of Ukraine, Kyiv, Ukraine

\section{ЗАБІЙНІ ЯКОСТІ КУРЧАТ-БРОЙЛЕРІВ ЗА ВИКОРИСТАННЯ ПРЕБІОТИЧНОГО ПРЕПАРАТУ АКТИГЕН}

\author{
Чернікова Ганна, Прокопенко Наталія
}

Received 26. 6. 2017

Revised 28. 6. 2017

Published 25. 11. 2017

Biologically active agents were proposed like inciter of animals growing and alternative of feed antibiotics and hormonal products. Prebiotic compounds are the most effective, because they have a positive effect on productivity, safety, immunity status, suppression of pathogenic microflora. Prebiotic doesn't have negative consequences. One of the most common prebiotic in Ukraine is Actigen. It is a highly purified, concentrate and specific controlled carbohydrate fraction, which was obtained from the cell wall of Saccharomyces cerevisiae. Actigen adding to broiler combined feed was learned in the poultry farm's conditions. We learned product influence on slaughter quality of broilers. We recommended adding a preparation in large quantity based on the previous research of grain feed quality in the Ukrainian market. Company-developer proposed to use Actigen in quantity $400 \mathrm{~g} / \mathrm{T}$ during all growing process. We proposed to use following quantity of Actigen in combine feed: starter $-800 \mathrm{~g} / \mathrm{T}$, growth $1-600 \mathrm{~g} / \mathrm{T}$, growth 2-400 g/T, finish 1-400 g/T, finish 2-300 g/T. According to the results of chicken broilers growing up to 42-day and holding a control, slaughter were receive increasing of preslaughter weight on $183.4 \mathrm{~g}$, or $7.38 \%(P \leq 0.05)$. Analysis of proceeding broiler chicken meat had shown the most changing of ratio different part the carcass. Received data showed that using of Actigen in proposed quantity for chicken broilers growing more expediency than recommended dosage.

Keywords: prebiotic; broiler-chickens; slaughter; quality; feed

\section{Вступ}

На сучасному етапі функціонування галузі птахівництва в Україні питання виробництва якісної і безпечної продукції, зокрема, продуктів забою курчат-бройлерів, вирішується впровадженням інтенсивних технологій, які передбачають застосування сучасних наукових розробок у виробничий процес.

У зв'язку із існуючою у країнах Євросоюзу, а також в Україні забороною щодо застосування кормових антибіотиків та гормональних препаратів як стимуляторів росту тварин, в тому числі курчат-бройлерів (Пентилюк, 2005, Стегній та Гужвицька, 2005), виникає питання щодо оптимізації їх годівлі й умов утримання. Як альтернатива антибіотикам на сьогодні уже

*Corresponding author: Ganna Chernikova, National University of Life and Environmental Sciences of Ukraine, Kyiv, Ukraine, $\bowtie$ anna-vol@ukr.net 
відомі пробіотики, пребіотики, ферментні препарати, мананоолігосахариди, біостимулятори, антиоксиданти, транквілізатори, бактеріостатики тощо (Свеженцов и Коробко, 2004; Околелова и др., 2010; Чернікова та Пономаренко, 2016). Досить ефективними у цьому відношенні визнані про-і пребіотики, які позитивно впливають на продуктивність, збереженість птиці, стимулюють імунітет, пригнічують умовно-патогенну мікрофлору кишечнику та не спричиняють негативних наслідків.

Покращання споживання та підвищення ефективності використання кормів, одержання максимальної продуктивності тварин забезпечується високим рівнем збалансованої годівлі з використанням різних кормових добавок. Аналіз спеціальної літератури показав, що на даному етапі розвитку комбікормової промисловості в годівлі тварин застосувується чимало кормових добавок (Поліщук, Білик, Небилиця, 2009)

Пребіотики - це неперетравлювані компоненти корму, які вибірково стимулюють ріст або активність захисної мікрофлори кишковика і поліпшують тим самим здоров'я. Їх призначають для нормалізації мікробіоценозу кишковика в ранній постнатальний період; при лікуванні антибіотиками і сульфаніламідними препаратами; для профілактики дисбактеріозів і інших шлунково-кишкових захворювань; як лікувально-профілактичні засоби для ослабленого організму; при стресових ситуаціях. Один з перших пребіотиків, який був завезений в Україну, $\epsilon$ Актиген.

Актиген (Alltech, Inc) - це високоочищена, концентрована, специфічна контрольована фракція вуглеводів, яку отримують з стінки клітин Saccharomyces cerevisiae.

Курчата-бройлери сучасних інтенсивних кросів відзначаються високою інтенсивністю росту, особливо у перші тижні життя, збільшуючи початкову живу масу у 3,5 - 5,0 разів, що вимагає надзвичайно ретельного балансування повнораціонних комбікормів за енергією і всіма необхідними елементами живлення та біологічно активними речовинами.

Метою нашого дослідження $\epsilon$ вивчення впливу введення препарату Актиген до складу комбікормів для курчат-бройлерів на їх забійні якості.

\section{Матеріали та методи}

Дослідження проведені в умовах птахівничого підприємства по вирощуванню курчатбройлерів. Для дослідів було сформовано дві групи курчат-бройлерів кросу «Росс 308» - дослідна і контрольна по 24000 гол. Курчатам дослідної групи до раціону вводили препарат Актиген, курчата контрольної групи отримували комбікорм без введення пребіотичного препарату.

Умови утримання і годівлі птиці відповідали існуючим вимогам. Застосовували 5-фазову годівлю птиці, використовуючи раціони: стартерний (з добового до 7-добового віку), ростовий 1 (8 - 15 доба вирощування), ростовий 2 (16 - 25 доба), фінішний 1 (26 - 35 доба), фінішний 2 (з 36 - 42 добу).

Згідно інструкцій компанії-виробника препарат Актиген має вводитись до складу комбікорму з розрахунку 400 г/т. На основі попередньо проведених комплексних досліджень якості кормів зернової групи на українському ринку, нами було рекомендовано збільшення дози вводу Актигену з першої до 15 доби відгодівлі. Тому препарат вводили у дозах, г/т: стартерний комбікорм - 800, ростовий $1-600$, ростовий $2-400$, фінішний $1-400$, фінішний $2-300$.

Курчат-бройлерів вирощували до 42-добового віку, за результатами вирощування визначали передзабійну живу масу. За результатами контрольного забою курчат-бройлерів (по 3 півники з кожної групи) провели анатомо-морфологічний аналіз тушок бройлерів за загальноприйнятими методиками. Біометричну обробку даних здійснювали за допомогою програмного забезпечення MS Excel з використання вбудованих статистичних функцій. 


\section{Результати та їх обговорення}

У результаті досліджень було виявлено вплив введення пребіотичного препарату Актиген до складу комбікормів на показники забою курчат-бройлерів (табл. 1).

Таблиця 1 Забійні якості курчат-бройлерів

Table 1 Slaughter properties of broiler-chickens

\begin{tabular}{|c|c|c|}
\hline Показник & 1 група (контроль) & 2 група (дослід) \\
\hline Передзабійна жива маса, г & $2484,9 \pm 56,82$ & $2668,3 \pm 30,02^{*}$ \\
\hline Маса тушки, г & $1949,0 \pm 65,98$ & $2118,4 \pm 24,43$ \\
\hline Вихід патраної тушки, \% & 78,44 & 79,39 \\
\hline \multicolumn{3}{|l|}{ Вихід окремих частин тушки: } \\
\hline $\begin{array}{l}\text { Грудні м’ язи, г } \\
\%\end{array}$ & $\begin{array}{c}580,1 \pm 20,55 \\
29,76\end{array}$ & $\begin{array}{c}629,6 \pm 46,15 \\
29,72\end{array}$ \\
\hline $\begin{array}{c}\text { Крила, r } \\
\%\end{array}$ & $\begin{array}{c}201,27 \\
10,33\end{array}$ & $\begin{array}{c}192,6 \pm 5,84 \\
9,09\end{array}$ \\
\hline $\begin{array}{c}\text { Стегно, r } \\
\%\end{array}$ & $\begin{array}{c}328,9 \pm 25,69 \\
16,87\end{array}$ & $\begin{array}{c}335,4 \pm 9,70 \\
15,83\end{array}$ \\
\hline $\begin{array}{c}\text { Гомілка, r } \\
\text { \% }\end{array}$ & $\begin{array}{c}273,0 \pm 5,67 \\
14,00\end{array}$ & $\begin{array}{c}274,5 \pm 8,56 \\
12,96\end{array}$ \\
\hline $\begin{array}{c}\text { Каркас, г } \\
\%\end{array}$ & $\begin{array}{c}555,7 \pm 53,74 \\
28,51\end{array}$ & $\begin{array}{c}683,9 \pm 68,32 \\
32,28\end{array}$ \\
\hline
\end{tabular}

*P $P 0.05$

Абсолютні значення показників забою курчат-бройлерів відповідають живій масі, яка була найвищою у курчат дослідної групи. Так, за передзабійною живою масою курчата цієї групи вірогідно $(P<0,05)$ перевищували масу птиці контрольної групи на 183,4 г, або 7,38 \%. За показниками маси патраної тушки курчата 2-ї дослідної групи переважали ровесників контрольної групи на 169,4 г, або 8,69%. При цьому вихід патраної тушки є вищим на 0,95 \%.

Встановлено відмінності і за виходом окремих частин тушки. Відзначимо перевагу птиці дослідної групи за масою найбільш цінних частин тушки, але за відносним значенням ця різниця була у межах похибки. За масою грудних м’язів значення у птиці дослідної групи були вищими за ровесників контрольної на 49,5 г, або 8,53 \%, маси стегна - на 6,5 г, або 0,97 \%, маси гомілок - 1,5 г, або 0,54 \%. При порівнянні маси крил значення у птиці дослідної групи були меншими за контрольну на 8,67 г, або 4,31%. Стосовно виходу каркасу тушки - вищими значення відмічено у птиці дослідної групи - на 128,2 г, або 23, 07 \%.

\section{Висновки}

На основі проведених досліджень щодо вивчення впливу введення пребіотичного препарату Актиген до складу комбікормів для курчат-бройлерів на їх забійні якості встановлено підвищення передзабійної живої маси курчат-бройлерів на 183,4 г, або 7,38 \% $(P \leq 0,05)$, виходу та маси патраної тушки - на 0,95\% та 169,4 г, або 8,69 \%, а також виходу найбільш цінних частин тушки. Отримані дані свідчать про доцільність використання препарату у запропонованих дозах при вирощуванні курчат-бройлерів. 


\section{Література}

Околелова, Т.М., Кузнецов, А.С., Савченко, В.С. 2010. Препарат Форми в комбикормах для бройлеров. Ефективне птахівничтво, № 4, с. 37-39.

Поліщук, А.А., Білик, О.В., Небилиця, М.С. 2009. Використання Сукраму-810 і Мацерази в раціонах годівлі молодняку свиней. Вісник Черкаського інституту агропромислового виробництва, № 9, с. 37-41.

Пентилюк, С. І. 2005. Сучасні кормові біопрепарати. Тваринництво України, № 6, с. 25-26.

Поліщук, А.А., Білик, О.В., Небилиця, М.С. 2009. Використання Сукраму-810 і Мацерази в раціонах годівлі молодняку свиней. Вісник Черкаського інституту агропромислового виробничтва, № 9, с. 37-41.

Свеженцов, А.И., Коробко, В.Н., 2004. Нетрадиционные кормовые добавки для животных и птицы. Днепропетровск: Арт-Пресс. 296 с.

Стегній, Б., Гужвицька, С. 2005. Застосування пробіотиків у тваринництві. Ветеринарна медицина України, № 5, с. 39-41.

Чернікова, Г.Ю., Пономаренко, Н.П. 2016. Використання пребіотиків на основі мананових олігосахаридів у годівлі курчат-бройлерів. Вісник аграрної науки Причорномор'я, вип. 2 (90), № 2, c. $155-160$. 